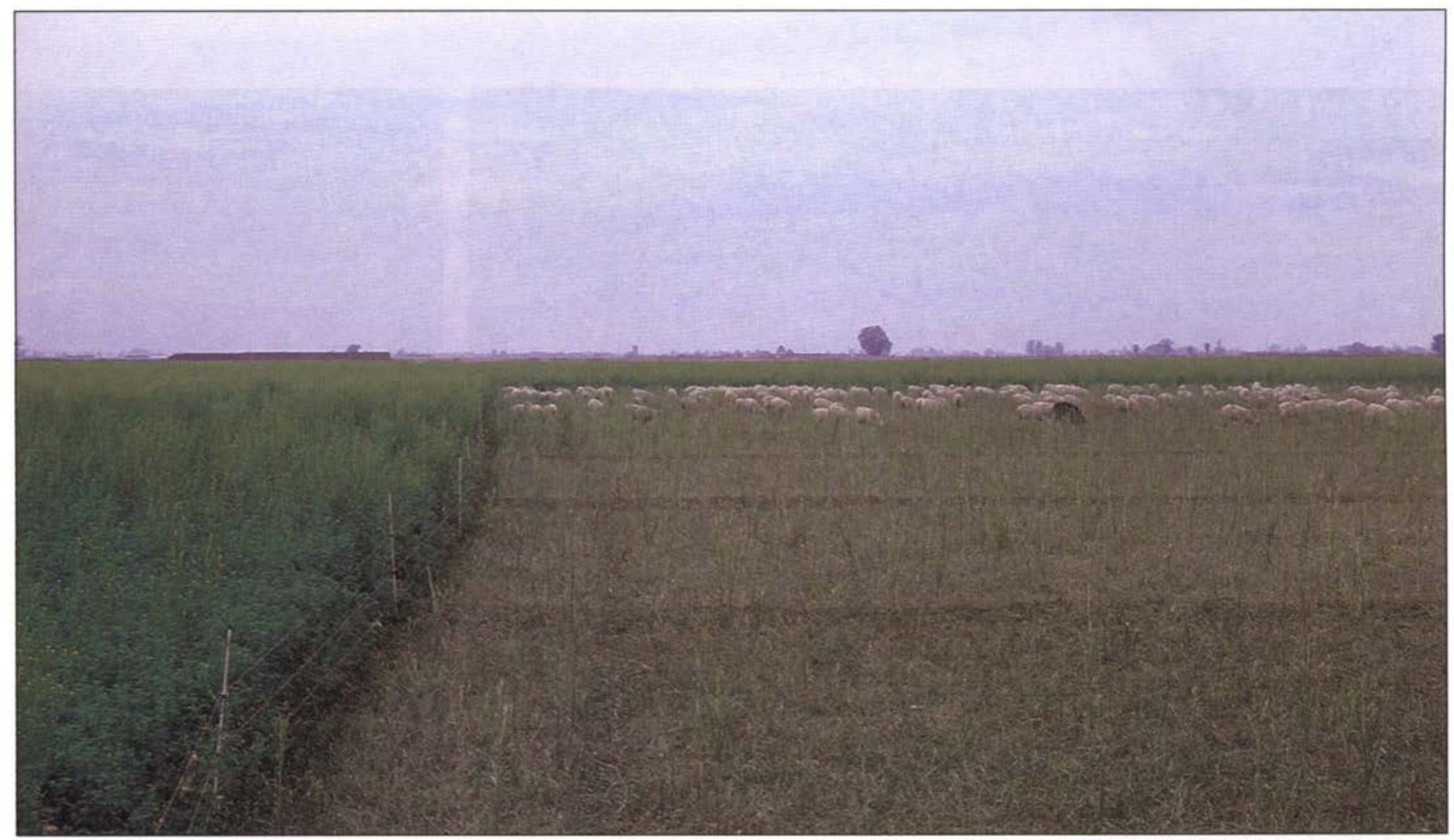

The view above shows the grazed area and the uneaten area to the left. Stems of London rocket (Systimbrium irio) can be seen along with grazed alfalfa.

\title{
Sheep grazing effectively controls weeds in seedling alfalfa
}

\author{
Carl E. Bell $\square$ Juan N. Guerrero
}

\section{A 3-year experiment compared sheep grazing to herbicides for weed control in seedling alfalfa in the Imperial Valley. Yields for the first season were highest with the grazed treatment and the un- treated control because of the contribution of weeds to the hay. There was no difference in the al- falfa forage yield and density among any of the treatments. Lambs preferred weeds to the al- falfa, and the nutritional value of the weeds was usually compa- rable to that of the alfalfa.}

The largest concentration of alfalfa in the world is reportedly in the Imperial Valley, which averaged 182,000 acres from 1990 through 1994. This amounts to $40 \%$ of the irrigated farm land in the valley. Alfalfa is generally planted in the fall, around Oct. 15, and remains 3 to 4 years before being rotated to another crop. Annual weeds that germinate with the crop are managed with herbicides, by harvesting as part of the first or second hay crops, or by sheep grazing fields as the first harvest.

During this same 5-year period, an average of 290,000 sheep grazed annually in the Imperial Valley. Sheep graziers bring lambs, weighing about 70 pounds, into the valley in the fall and graze them on alfalfa fields until spring, when they are sold at a finished weight of 130 pounds. When the sheep first arrive in the valley, they are grazed on established alfalfa fields, sudangrass or vegetable residues. The sheep graziers pay the alfalfa grower a negotiated price, typically $\$ 0.06$ to $\$ 0.11$ per head per day, as a pasturing fee. The lambs graze a field, usually for 10 to 14 days, until the standing hay is eaten down to 2 inches of stubble. This grazing substitutes for a hay harvest. The sheep grazier supplies fencing and water for the lambs and moves them between fields.

In late winter, starting in January, sheep are moved to seedling alfalfa fields. These fields are typically very weedy because no herbicides have been used. The role of the sheep is to eat the weeds along with the alfalfa. Alfalfa growers who rent fields for sheep grazing believe that grazing is a good weed-control practice. Other alfalfa growers in the Imperial Valley do not allow grazing because they think sheep are detrimental to a new field and a source of weed seed through their droppings and in their wool. These growers also feel that the best 


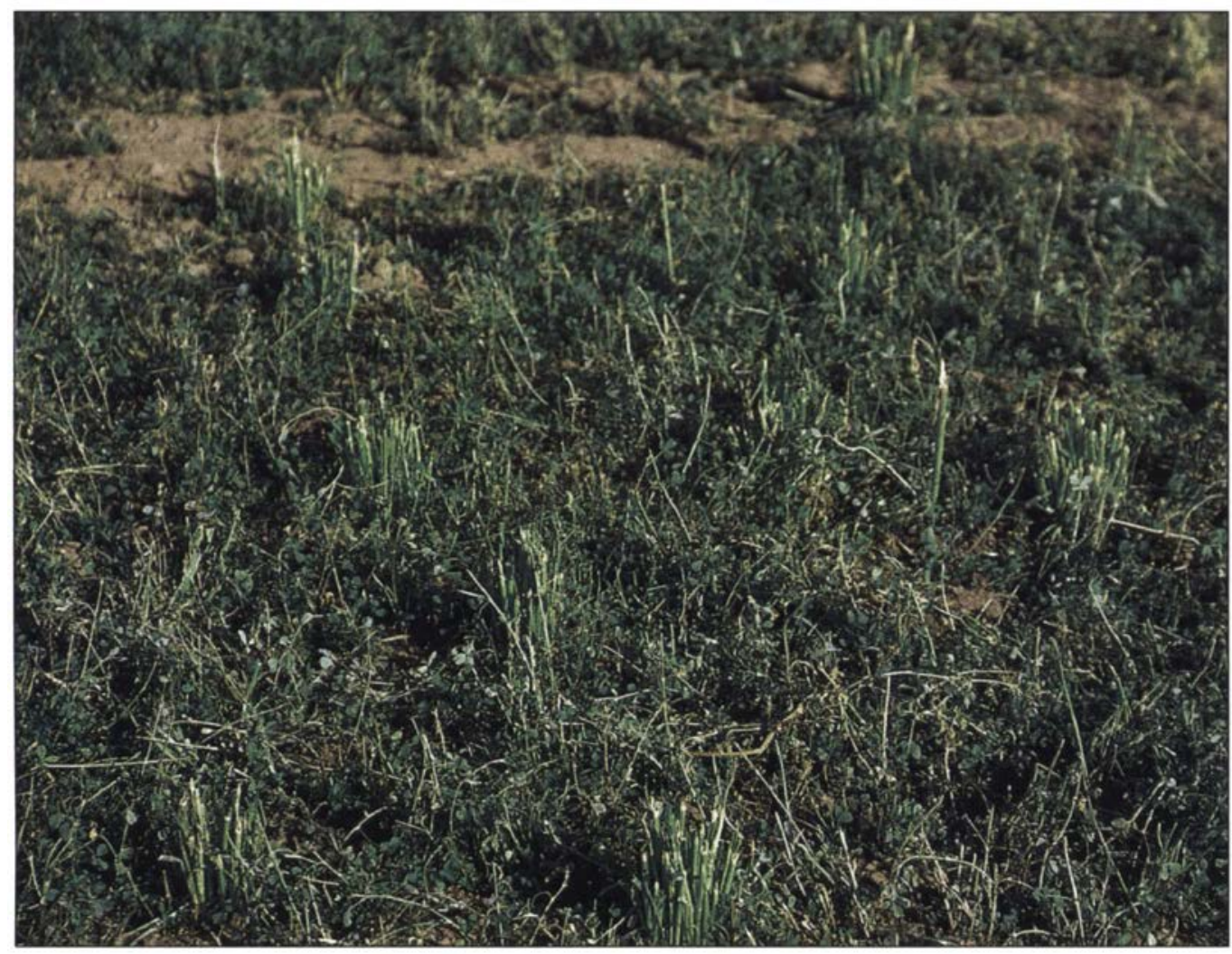

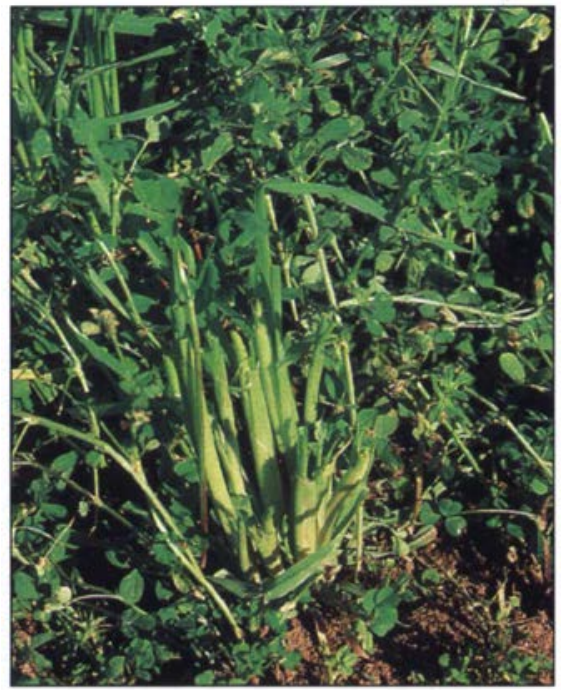

$\Delta$ The sheep have nibbled the volunteer wheat and left the alfalfa standing.

\section{One of the sheep-grazing plots after a few days of grazing.}

TABLE 1. Dates for activities and herbicide application rates for a study comparing weed-control methods in seedling alfalfa in the Imperial Valley

\begin{tabular}{|c|c|c|c|}
\hline Year* & 1990 & 1991 & 1992 \\
\hline Planting date & Oct 25, 1989 & Oct 29,1990 & Nov 7, 1991 \\
\hline \multicolumn{4}{|l|}{ Weed-control treatment } \\
\hline \multicolumn{4}{|l|}{ Sheep grazing } \\
\hline Began & Jan 29, 1990 & Feb 18,1991 & Feb 27, 1992 \\
\hline Ended & Feb 22, 1990 & Feb 28, 1991 & Mar 23, 1992 \\
\hline Total days & 24 & 10 & $20 t$ \\
\hline Rainfall, inches & 0.35 & 0.44 & 0.75 \\
\hline Untreated control & Feb 23, 1990 & Mar 1, 1991 & Mar 24, 1992 \\
\hline \multicolumn{4}{|l|}{ Herbicide 1} \\
\hline Preplant - EPTC, $3.5 \mathrm{lbai} / \mathrm{A}$ & Oct 5,1989 & Oct 17,1990 & Nov 4,1991 \\
\hline \multicolumn{4}{|l|}{ Postemergence } \\
\hline 2,4-DB amine, $1.0 \mathrm{lbae} / \mathrm{A}$ & Dec 21, 1989 & Jan 28, 1991 & $\operatorname{Jan} 14,1992$ \\
\hline sethoxydim, $0.38 \mathrm{lbai} / \mathrm{A}$ & Dec 21, 1989 & Jan 28,1991 & Jan 14,1992 \\
\hline \multicolumn{4}{|l|}{ Herbicide 2} \\
\hline \multicolumn{4}{|l|}{ Postemergence } \\
\hline 2,4-DB amine, $1.0 \mathrm{lbae} / \mathrm{A}$ & Dec 21, 1989 & Jan 28, 1991 & Jan 14,1992 \\
\hline sethoxydim, $0.38 \mathrm{lbai} / \mathrm{A}$ & Dec 21, 1989 & Jan 28, 1991 & Jan 14,1992 \\
\hline \multicolumn{4}{|l|}{ Harvest dates $\ddagger$} \\
\hline \multicolumn{4}{|l|}{ First season } \\
\hline First & Jan 25,1990 & Feb 13, 1991 & Feb 26, 1992 \\
\hline Second & Apr 20,1990 & Apr 22, 1991 & Apr 27,1992 \\
\hline Third & May 11,1990 & May 23,1991 & June 8,1992 \\
\hline Fourth & June 18,1990 & June 21,1991 & July 22,1992 \\
\hline Sixth & Aug 20,1990 & Aug 28, 1991 & not taken \\
\hline \multicolumn{4}{|l|}{ Second season } \\
\hline First & Feb 26, 1991 & Jan 15, 1992 & Feb 10, 1993 \\
\hline
\end{tabular}

"Year refers to the calendar year when grazing occurred.

†Rain caused a 5 -day break in this grazing period.

¥Yield estimates were not taken for the fifth and seventh harvests of the first season for this experiment. economic value is achieved by producing weed-free hay that sells for the highest price per ton to the dairy market. A third group of alfalfa growers are of the opinion that weed control is unnecessary - that weeds disappear from a field after the second or third harvest and do not return, and that the increased tonnage of the weedy hay offsets its lower price.

All three viewpoints on how to manage weeds in a seedling alfalfa field are strongly held by their respective growers, who seldom change their practices. Locally developed information or research to support any one viewpoint could not be found. We established an experiment to compare weed-control practices - herbicides, sheep grazing and harvesting - for their effect on alfalfa stand density, yield, and weediness of the hay. We also evaluated feeding preferences of sheep in weedy alfalfa and the feed value of common winter annual weeds growing in the area.

\section{Four experimental treatments}

The experiment was repeated 3 years at the UC Desert Research and 
Extension Center near Holtville. Each "year" of this experiment lasted about 16 months, starting with the planting of the alfalfa in the fall; continuing with grazing the following winter; and completing with harvests taken through the spring, summer and fall and at the first spring harvest of the second season of each crop. Each "year" of the experiment is identified by the calendar year when the grazing took place.

The four experimental treatments were two herbicide regimes, sheep grazing and an untreated control (table 1). Alfalfa in the Imperial Valley is grown on flat ground called lands, typically 70 feet wide, between raised irrigation borders. A randomized complete block design was used, with three lands serving as blocks. Two sub-block replicates were used in each

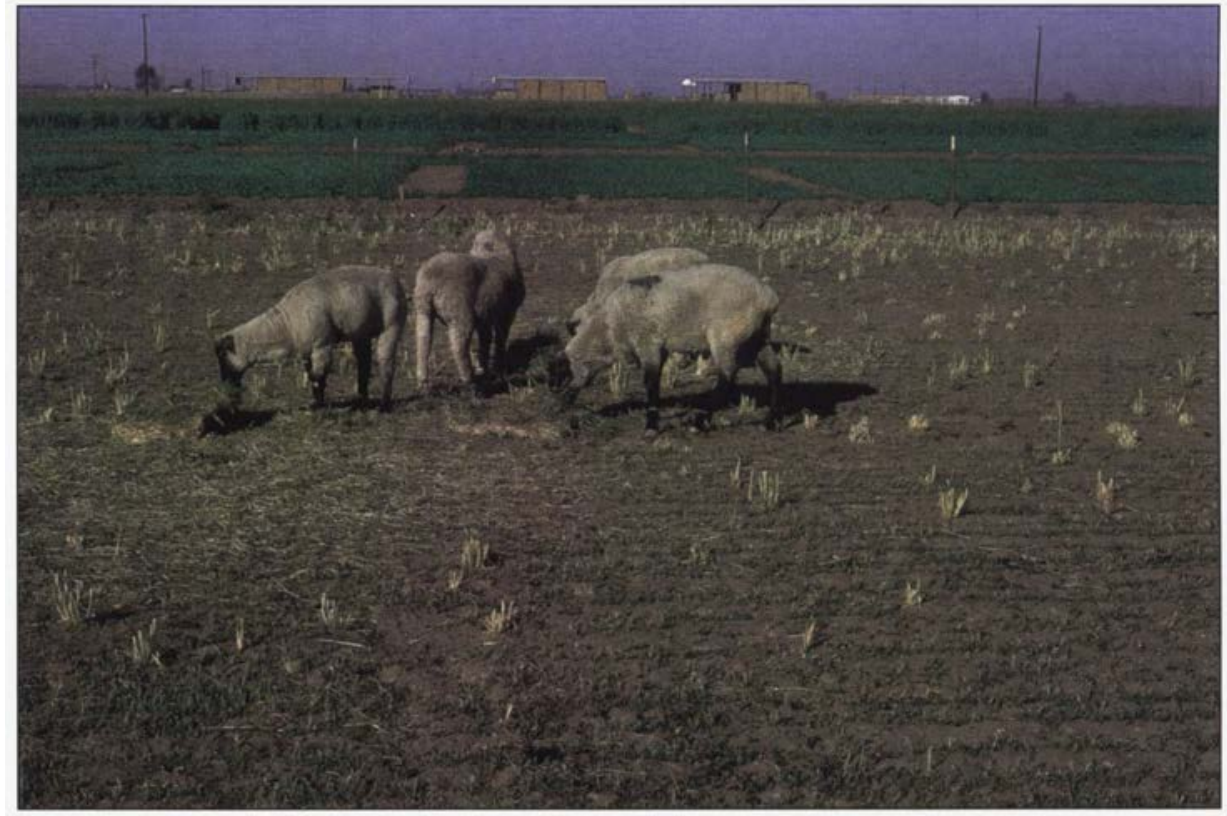

A thoroughly grazed plot (22 days total) in the first year of the experiment. The sheep have left no forage in the field.

TABLE 2. Alfalfa and weed yield* as affected by weed-management treatment to seedling alfalfa, 1990-92

\begin{tabular}{|c|c|c|c|c|c|c|c|c|c|c|c|}
\hline \multirow[b]{3}{*}{ Factor } & \multicolumn{10}{|c|}{ Harvests } & \multirow{2}{*}{$\begin{array}{c}\text { 1st harvest of } \\
\text { following } \\
\text { year }\end{array}$} \\
\hline & \multicolumn{2}{|c|}{1 st } & \multicolumn{2}{|c|}{ 2nd } & \multicolumn{2}{|c|}{ 3rd } & \multirow{2}{*}{$\frac{\text { 4th }}{\text { Alfalfa }}$} & \multirow{2}{*}{$\frac{\text { 6th }}{\text { Alfalfa }}$} & \multicolumn{2}{|c|}{ Cumulative } & \\
\hline & Alfalfa & Weeds & Alfalfa & Weeds & Alfalfa & Weeds & & & Alfalfa & weeds & Alfalfa \\
\hline & & & & ....... $\mathrm{lb} /$ & & & (1) & & .... ton $/ a$ & re.. & Ib/acre \\
\hline 1990 & $1,093 \mathrm{bt}$ & 330 & $1,359 b$ & $651 \mathrm{a}$ & $2,057 b$ & 33 & $3,170 \mathrm{a}$ & 1,401 & $4.5 \mathrm{ab}$ & $5.0 \mathrm{a}$ & $1,831 \mathrm{~b}$ \\
\hline 1991 & $805 \mathrm{~b}$ & 397 & $1,409 \mathrm{~b}$ & 531 a & $1,510 \mathrm{c}$ & 0 & $2,333 \mathrm{~b}$ & 1,360 & $3.7 \mathrm{~b}$ & $4.2 \mathrm{~b}$ & $1,200 \mathrm{c}$ \\
\hline 1992 & $1,930 \mathrm{a}$ & 542 & $2,012 \mathrm{a}$ & $84 \mathrm{~b}$ & $3,479 \mathrm{a}$ & 0 & $2,904 \mathrm{a}$ & - & $5.2 \mathrm{a}$ & $5.5 \mathrm{a}$ & 2,110 a \\
\hline \multicolumn{12}{|c|}{ Weed-control method‡ } \\
\hline GR & $1,505 \mathrm{a}$ & $633 \mathrm{a}$ & 1,354 & 528 & 2,256 & 27 & 2,874 & 1,467 & 4.5 & $5.1 \mathrm{a}$ & 1,757 \\
\hline UT & $1,502 \mathrm{a}$ & 765 a & 1,570 & 577 & 2,408 & 4 & 2,794 & 1,413 & 4.6 & $5.3 \mathrm{a}$ & 1,677 \\
\hline $\mathrm{H} 1$ & $1,074 \mathrm{~b}$ & $82 \mathrm{~b}$ & 1,721 & 239 & 2,434 & 0 & 2,763 & 1,356 & 4.4 & $4.6 \mathrm{~b}$ & 1,695 \\
\hline $\mathrm{H} 2$ & $1,023 \mathrm{~b}$ & $211 b$ & 1,727 & 344 & 2,296 & 12 & 2,777 & 1,292 & 4.3 & $4.6 \mathrm{~b}$ & 1,724 \\
\hline \multicolumn{12}{|c|}{$\begin{array}{l}\text { Year } \times \text { weed-control method } \\
1990\end{array}$} \\
\hline GR & $1,165 \mathrm{bc}$ & 364 & $1,334 d$ & $366 \mathrm{bcd}$ & 1,835 & 82 & 3,246 & 1,529 & 4.6 & 5.0 & 1,876 \\
\hline UT & $1,156 \mathrm{bc}$ & 698 & $1,171 \mathrm{~d}$ & $1,028 \mathrm{a}$ & 2,101 & 12 & 3,142 & 1,434 & 4.5 & 5.4 & 1,789 \\
\hline $\mathrm{H} 1$ & $1,104 \mathrm{bc}$ & 11 & 1,575 bcd & $351 \mathrm{bcd}$ & 2,271 & 0 & 3,211 & 1,463 & 4.8 & 5.0 & 1,827 \\
\hline $\mathrm{H} 2$ & $948 \mathrm{~cd}$ & 248 & $1,355 d$ & $858 a b$ & 2,022 & 36 & 3,080 & 1,180 & 4.3 & 4.9 & 1,830 \\
\hline \multicolumn{12}{|l|}{1991} \\
\hline GR & $1,082 b c$ & 610 & $1,160 \mathrm{~d}$ & $1,000 \mathrm{a}$ & 1,482 & 0 & 2,387 & 1,394 & 3.8 & 4.6 & 1,276 \\
\hline UT & $1,102 \mathrm{bc}$ & 591 & $1,450 \mathrm{~d}$ & $623 a b c$ & 1,574 & 0 & 2,332 & 1,393 & 3.9 & 4.5 & 1,194 \\
\hline $\mathrm{H} 1$ & $515 d$ & 165 & $1,483 d$ & $338 \mathrm{bcd}$ & 1,458 & 0 & 2,328 & 1,250 & 3.5 & 3.8 & 1,167 \\
\hline $\mathrm{H} 2$ & $519 d$ & 223 & $1,542 \mathrm{~cd}$ & $162 \mathrm{~cd}$ & 1,524 & 0 & 2,286 & 1,405 & 3.6 & 3.8 & 1,162 \\
\hline \multicolumn{12}{|l|}{1992} \\
\hline GR & $2,269 \mathrm{a}$ & 927 & $1,568 \mathrm{bcd}$ & $219 \mathrm{~cd}$ & 3,450 & 0 & 2,990 & $-\S$ & 5.1 & 5.7 & 2,119 \\
\hline UT & $2,246 \mathrm{a}$ & 1,007 & $2,091 \mathrm{abc}$ & $79 \mathrm{~cd}$ & 3,552 & 0 & 2,907 & - & 5.4 & 5.9 & 2,048 \\
\hline $\mathrm{H} 1$ & $1,603 \mathrm{~b}$ & 69 & $2,105 a b$ & $27 d$ & 3,574 & 0 & 2,752 & - & 5.0 & 5.1 & 2,092 \\
\hline $\mathrm{H} 2$ & $1,602 \mathrm{~b}$ & 163 & $2,283 a$ & $12 d$ & 3,341 & 0 & 2,966 & - & 5.1 & 5.2 & 2,179 \\
\hline
\end{tabular}

"Yield in lb/acre at $90 \%$ dry weight basis, except for cumulative yield at ton/acre at $90 \%$ dry weight, least square means of 3 blocks, 2 replications per block. † Numbers in a column, within a factor, followed by the same letter are not different (P>.05) according to Fisher's Protected LSD.

$\ddagger$ Treatments: GR - grazing with sheep at the first harvest; UT — untreated, harvesting (mowing) weeds with alfalfa at the first harvest;

$\mathrm{H} 1$ - preplant herbicide plus postemergence herbicides; $\mathrm{H} 2$ - postemergence herbicides only.

$\S$ Because of insect injury to alfalfa, the crop was not harvested at the normal time during this year; therefore yield samples were not taken. 
TABLE 3. Mean alfalfa and weed densities* related to weed-management treatment at three harvests, 1990-92

\begin{tabular}{|c|c|c|c|c|c|}
\hline \multirow[b]{3}{*}{ Factor } & \multicolumn{4}{|c|}{ 1st season } & \multirow{3}{*}{$\frac{\frac{2 \text { nd season }}{\text { 1st harvest }}}{\text { Alfalfa }}$} \\
\hline & \multicolumn{2}{|c|}{ 1st harvest } & \multicolumn{2}{|c|}{ 2nd harvest } & \\
\hline & Alfalfa & Weeds & Alfalfa & Weeds & \\
\hline & $\ldots$ & ....... & ints per squ & foot .... & ............... \\
\hline \multicolumn{6}{|l|}{ Year } \\
\hline 1990 & 32.6 at & 0.94 & $27.8 \mathrm{a}$ & 0.58 & $17.0 \mathrm{a}$ \\
\hline 1991 & $27.3 \mathrm{a}$ & 0.97 & $25.2 \mathrm{a}$ & 0.81 & $8.4 \mathrm{~b}$ \\
\hline 1992 & $16.7 b$ & 0.93 & $20.3 b$ & 0.21 & $8.2 \mathrm{~b}$ \\
\hline \multicolumn{6}{|c|}{ Weed-control method $\ddagger$} \\
\hline GR & 26.7 & $1.20 \mathrm{ab}$ & 27.1 & 0.96 & 11.5 \\
\hline MO & 25.7 & $1.46 \mathrm{a}$ & 22.3 & 0.71 & 11.4 \\
\hline $\mathrm{H} 1$ & 24.9 & $0.41 \mathrm{c}$ & 23.8 & 0.17 & 11.3 \\
\hline $\mathrm{H} 2$ & 24.8 & $0.73 \mathrm{bc}$ & 24.7 & 0.31 & 10.6 \\
\hline \multicolumn{6}{|c|}{ Year $\times$ weed-control method } \\
\hline \multicolumn{6}{|c|}{1990} \\
\hline GR & 32.5 & 1.1 & $30.1 \mathrm{a}$ & 0.5 & 16.9 \\
\hline MO & 34.7 & 1.8 & $22.8 \mathrm{~cd}$ & 1.0 & 17.5 \\
\hline $\mathrm{H} 1$ & 33.9 & 0.1 & $29.6 \mathrm{a}$ & 0.2 & 18.0 \\
\hline $\mathrm{H} 2$ & 29.2 & 0.8 & $28.7 \mathrm{ab}$ & 0.6 & 15.6 \\
\hline 1991 & & & & & \\
\hline GR & 31.2 & 1.2 & $33.0 \mathrm{a}$ & 1.8 & 9.3 \\
\hline MO & 25.8 & 1.1 & $22.5 \mathrm{~cd}$ & 0.9 & 8.4 \\
\hline $\mathrm{H} 1$ & 23.5 & 0.7 & $21.3 \mathrm{~cd}$ & 0.3 & 8.1 \\
\hline $\mathrm{H} 2$ & 28.6 & 0.8 & $24.0 \mathrm{bc}$ & 0.3 & 7.8 \\
\hline \multicolumn{6}{|l|}{1992} \\
\hline GR & 16.3 & 1.3 & $18.0 \mathrm{~d}$ & 0.6 & 8.4 \\
\hline MO & 16.6 & 1.5 & $21.6 \mathrm{~cd}$ & 0.2 & 8.3 \\
\hline $\mathrm{H} 1$ & 17.2 & 0.4 & $20.3 \mathrm{~cd}$ & $<0.1$ & 7.9 \\
\hline $\mathrm{H} 2$ & 16.6 & 0.6 & $21.4 \mathrm{~cd}$ & $<0.1$ & 8.3 \\
\hline
\end{tabular}

"Number per square foot, mean of two replications in three blocks.

†Numbers in a column, within a factor, followed by the same letter are not different $(P=0.05)$ according to Fisher's Protected LSD.

$\ddagger$ Treatments: GR - grazing with sheep at the first harvest; MO - harvesting (mowing) weeds with alfalfa at the first harvest; $\mathrm{H} 1$ - preplant herbicide plus postemergence herbicides; $\mathrm{H} 2$ — postemergence herbicides only.

TABLE 4. Chemical composition of common winter annual weeds in seedling alfalfa in the irrigated Sonoran Desert, 1991-92

\begin{tabular}{|c|c|c|c|c|c|c|}
\hline Species* & $\mathrm{CPt}$ & NDF & ADF & ADL & & Ash \\
\hline & & & $\%$ & 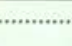 & $\cdots$ & $\ldots . .$. \\
\hline $\begin{array}{l}1991 \\
\text { Alfalfa }\end{array}$ & 18.4 & 26.2 & 20.9 & 4.4 & & 11.7 \\
\hline Nettleleaf goosefoot & 28.7 & 14.3 & 10.7 & 2.1 & & 21.0 \\
\hline Little mallow & 28.8 & 15.3 & 13.7 & 1.9 & & 6.6 \\
\hline Volunteer wheat & 18.4 & 44.2 & 22.6 & 2.6 & & 9.8 \\
\hline Wild oats & 10.5 & 42.5 & 24.9 & 2.0 & & 10.7 \\
\hline Littleseed canarygrass & 10.8 & 37.4 & 20.3 & 1.6 & & 10.5 \\
\hline London rocket & 21.7 & 30.5 & 24.4 & 4.8 & & 11.9 \\
\hline Annual sowthistle & 16.0 & 15.5 & 13.8 & 1.8 & & 18.0 \\
\hline \multicolumn{7}{|l|}{$1992 \ddagger$} \\
\hline Alfalfa & 26.7 & 30.2 & 23.3 & 5.5 & & 8.9 \\
\hline Nettleleaf goosefoot & 21.2 & 27.4 & 20.4 & 3.9 & . & 22.4 \\
\hline Little mallow & 14.5 & 34.1 & 26.4 & 4.5 & & 11.5 \\
\hline Volunteer wheat & 8.6 & 56.3 & 32.4 & 4.3 & & 7.3 \\
\hline Wild oats & 9.1 & 56.6 & 34.2 & 5.2 & & 7.8 \\
\hline Littleseed canarygrass & 12.8 & 54.7 & 32.3 & 3.7 & & 10.8 \\
\hline London rocket & 17.8 & 28.2 & 22.5 & 6.5 & & 8.4 \\
\hline Annual sowthistle & 19.5 & 21.7 & 21.4 & 2.5 & & 17.8 \\
\hline
\end{tabular}

- Nettleleaf goosefoot, Chenopodium murale L.; little mallow, Malva parviflora L.; volunteer wheat, Triticum aestivum L.; wild oats, Avena fatua L.; littleseed canarygrass, Phalaris minor Retz.; London rocket,

Sisymbrium irio L.; and annual sowthistle, Sonchus asper (L.) Hill.

†CP - crude protein; NDF — neutral detergent fiber; ADF - acid detergent fiber; ADL — acid detergent lignin.

$\ddagger$ Because of excessive rain in 1992, samples were taken at a later date than 1991 and were more physiologically mature. block. The four treatments were randomized within each replicate of the block. Plot size was 0.1 acre. Alfalfa 'CUF101', the most common variety in the Imperial Valley, was sown at $20 \mathrm{lb} /$ acre in the fall of each year about 0.25 inches deep, using a grain drill with a grass seeder box. The sown fields were flood-irrigated.

Alfalfa yield and density were estimated with quadrat samples. The day before grazing began, when the alfalfa was about 12 inches tall, five subsamples, each 2.69 square feet, were harvested by hand clipping at 2 inches in each plot. In each subsample, weeds and alfalfa were separated by species, placed in paper bags, dried in a forced-air oven at $122^{\circ} \mathrm{F}$ for 72 hours and then weighed. The number of alfalfa and weed plants in each quadrat were counted when they were clipped.

Four sheep were put together in each grazed plot; this stocking rate is equivalent to a typical band of 1,600 sheep on a 40 -acre field. The sheep were left in the field until they had eaten all of the available forage to a stubble height of 1 to 2 inches. This grazing period varied, mostly because of rain, from 24 days in 1990 to 10 days in 1991 to 20 days in 1992. At the completion of grazing, the whole field was harvested for hay, then irrigated to initiate regrowth for the second harvest.

We estimated forage yield and density at the second harvest in the same manner as at the first harvest. Yield estimates were also made at the third, fourth and sixth harvests each year to determine the long-term impact of each weed-control option on alfalfa yield. We made a final yield and density estimate the following spring when the field was ready to harvest for the first time in the second season of the crop (tables 2 and 3 ).

Lamb feeding preferences were determined by analyzing samples taken through the use of esophageal fistulas in three animals. One fistulated lamb was placed in plots with the grazing lambs in each block each day of the grazing period for about a half-hour. After the feeding sample was collected, these lambs were put in a 
nearby paddock with forage similar to that of the experimental lambs. A small subsample of the extrusa collected was floated in a shallow dish of water, and the weed and alfalfa particles were picked out separately. Each sample was dried and weighed to make a quantitative estimate of the percentages of alfalfa and weeds being eaten by the lambs on a daily basis. The nutritional value of the alfalfa and the weeds was determined in the laboratory from plants cut in the fields being grazed (table 4). We analyzed both weeds and alfalfa for crude protein, ash, neutral detergent fiber (NDF), acid detergent fiber (ADF) and acid detergent lignin.

\section{Alfalfa yield and density}

We included the year of the experiment as part of our statistical model because we expected it to have an important influence on results. In many cases, year was the most significant factor affecting crop density, hay yield and weediness (tables 2 and 3). Alfalfa farmers are well aware of the unpredictable effect of "year" (that is, factors such as weather, pests and farming practices) on crop production.

Weed control achieved with the two herbicide regimes was very good in all 3 years of the experiment. Weed density and yield were lower than in the grazed or untreated control plots at the first harvest. Herbicide treatment reduced forage yield an average of 550 pounds at the first harvest, compared to the grazed and untreated control. In two of the years, 1991 and 1992, crop injury from 2,4-DB reduced alfalfa growth $50 \%$ and $33 \%$, respectively.

In 1990, the year with the longest sheep-grazing period, weed yield and density at the second harvest in the grazed plots were comparable to those under herbicide treatment. Conversely, the year with the shortest grazing period, 1991, had the highest amount of weeds in the forage at this harvest. There was more variability between treatments and years at the second harvest than at any other harvest. Weed species that were most common at the second harvest were annual sowthistle, little mallow and wild oats. There were no differences related to treatment at the third, fourth or sixth harvest, and there were very few weeds in the hay.

Total alfalfa yield for the first season, not including the weeds, was almost equal between weedcontrol methods. Alfalfa forage yield and density, when measured at the first harvest of the second season of the crop, were also not affected by weed-control method, although there were year differences (table 2 , table 3 ). There were no weeds at this harvest.

\section{Lamb feeding preferences}

In this experiment, the lambs preferred weeds to alfalfa (fig. 1). It was not until the eighth day of grazing that the samples obtained from the lambs had the same percentage of alfalfa as was originally available in the field. Chemical analysis of the weeds compares favorably to alfalfa in many cases (table 4).

\section{Conclusions}

It was demonstrated that weed control in seedling alfalfa has only a temporary effect on alfalfa yield and quality, under typical conditions in the Imperial Valley. In fact, weed control reduces total forage yield. Therefore, the choice of weed-control method in seedling alfalfa should be determined by economic factors (such as hay price, discounts for weedy hay, the cost of spraying weeds and pasturing fees) and by agronomic factors (such as the ability to properly cure weedy hay in the field, the likelihood of rain and the availability of sheep).

Sheep readily consumed weeds in seedling alfalfa fields, usually in preference to the alfalfa. Sheep did as good a job of weed control as herbicides. Sheep represent an alternative weedcontrol method for seedling alfalfa in
Fig. 1. Percent alfalfa consumed by grazing lambs as determined from esophageal extrusa, means of 1991 and 1992 . The percentage of alfalfa available at start of grazing averaged $69.4 \%$ over 1991 and 1992. Regression equation: $Y=25.49+5.23(X)$ and $r^{2}=0.70(r=0.8353643)$ where $Y=\%$ alfalfa in lamb esophageal extrusa, $X=$ day of grazing.

the Imperial Valley. Chemical analysis of common winter weeds in the Imperial Valley shows that they have nutritive values similar to alfalfa and do not lower hay quality per se. No weeds were present that are known to cause off-flavors in cow's milk or that are known to be toxic to livestock; either of these factors would have an important influence on the choice of weed-control method in seedling alfalfa.

C.E. Bell is Weed Science Farm Advisor and J.N. Guerrero is Area Livestock Farm Advisor, UC Cooperative Extension, Imperial County. Partial funding for this project was provided by a grant from the UC Statewide IPM Program. We gratefully appreciate the assistance of Carol Adams, former UC Cooperative Extension Biometrician, on the design of the statistical model for this experiment. For the full research report, see Bell, C.E., Guerrero, J.N. and Granados, E.. 1996. A comparison of sheep grazing with herbicides for weed control in seedling alfalfa in the irrigated Sonoran Desert. J. Prod. Agric. 9:123-9. 